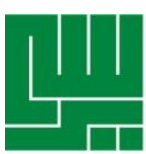

KATA KUNCI Kesadaran Kesehatan, Perilaku Menjaga Kesehatan, Obesitas.

KEYWORDS

ABSTRAK

\author{
Audi Destianty, Riselligia Caninsti
}

Fakultas Psikologi, Universitas YARSI, Jakarta, Indonesia

Email: riselligia.caninsti@yarsi.ac.id

\section{Peran Kesadaran Kesehatan terhadap Preventive Health Care Behavior pada Individu yang Mengalami Obesitas}

\section{The Role of Health Consciousness on Preventive Health Care Behavior in People with Obesity}

\begin{abstract}
Health Consciousness, Preventive Health Care Behavior, Obesity.
\end{abstract}

Kondisi obesitas menimbulkan dampak negatif kepada individu yang mengalaminya. Dampak negatif yang dirasakan oleh individu obesitas antara lain dampak fisik(seperti meningkatnya resiko mengalami penyakit kronis),dampak psikologis (seperti merasa kurang percaya diri), dan dampak sosial (berupa hambatan dalam berinteraksi dengan orang lain di lingkungan sosial). Kondisi tersebut membuat individu yang mengalami obesitas perlu melakukan tindakan pencegahan untuk meminimalkan dampak negatif dari obesitas. Tindakan untuk menjaga kesehatan melalui upaya pencegahan dinamakan dengan preventive health care behavior. Ada beberapa faktor yang berperan terhadap preventive health care behavior, salah satunya adalah kesadaran kesehatan (health consciousness). Kondisi obesitas dapat diatasi apabila individu melakukan beragam upaya untuk memelihara kesehatan, namun pada kenyataannya tidak semua individu yang mengalami obesitas memiliki kesadaran akan kesehatan. Penelitian ini bertujuan untuk menguji peran kesadaran kesehatan terhadap preventive health care behavior pada individu dewasa awal yang mengalami obesitas. Penelitian ini menggunakan pendekatan kuantitatif. Sampel penelitian berjenis kelamin laki-laki (43 orang) dan perempuan (39 orang), dengan total jumlah partisipan 82 orang usia dewasa awal yang mengalami obesitas di wilayah JABODETABEK. Teknik pengambilan sampel adalah accidental sampling. Instrumen pengumpulan data yang digunakan adalah Health Consciousness Scale $(\alpha=0.880)$ dan Preventive Behavior Scale $(\alpha=0.886)$. Data yang diperoleh melalui skala dianalisis menggunakan teknik analisis data uji regresi linear sederhana. Hasil penelitian menunjukan bahwa kesadaran kesehatan memiliki peran yang signifikan terhadap preventive health care behavior $(\mathrm{p}=.000, \mathrm{R} 2=.219)$. Artinya, individu obesitas yang memiliki kesadaran kesehatan akan berupaya untuk melakukan tindakan pencegahan demi menjaga kesehatan. Oleh sebab itu, seseorang yang mengalami obesitas perlu 
ABSTRACT

mengembangkan kesadaran kesehatan pada dirinya, sehingga dapat termotivasi dalam melakukan preventive health care behavior.

The condition of obesity has negative impacts and consequences on individuals who experience it. The negative impacts felt by obese individuals: physical impacts(such as the increased risk of chronic disease), psychological impacts (such as feeling less confident), and social impacts (in the form of barriers to interacting with other people in the social environment). This condition makes obese individuals need to take precautions not to experience the adverse effects of obesity. Actions to maintain health through preventive efforts are also known as preventive health care behaviors. Several factors play a role in preventive health care behavior, one of which is health consciousness. Obesity conditions can be overcome if individuals make various efforts to maintain health, but in reality not all individuals who are obese have health awareness. This study aims to determine the role of health consciousness on preventive health care behavior in early adult individuals who are obese. This study uses a quantitative approach. The study samples were male (43 people) and female (39 people), with a total number of participants 82 people of early adulthood who were obese in the JABODETABEK area. The sampling technique is accidental sampling. The data collection instruments used were the Health Consciousness Scale $(\alpha=0.880)$ and the Preventive Behavior Scale $(\alpha$ $=0.886)$. The data obtained through questionnaires were analyzed using simple linear regression data analysis techniques. The results showed that the variable health consciousness had a significant role in the preventive health care behavior variable $(p=.000, R 2=.219)$. The result means that obese individuals who have health awareness will try to take precautions to maintain health. Therefore, someone who is obese needs to develop health consciousness in himself to be motivated to do preventive health care behavior.

\section{PENDAHULUAN}

Obesitas merupakan salah satu faktor yang dapat mengganggu kesehatan. Jumlah individu dewasa yang mengalami obesitas di tahun 2014 diperkirakan mencapai 10,8\% pria (266 juta jiwa) dan 14,9\% wanita (375 juta jiwa) di seluruh dunia. Jumlah ini meningkat lebih dari dua kali lipat jika dibandingkan dengan jumlah individu dewasa yang mengalami obesitas pada tahun 1975, yaitu 3,2\% pada pria dan $6,4 \%$ pada wanita. Apabila tren ini terus berlanjut, maka diperkirakan pada tahun 2025, sebanyak $18 \%$ pria dan $21 \%$ wanita akan mengalami obesitas $=$ (Ansari, Haboubi, \& Haboubi, 2020).
Di negara-negara berkembang, prevalensi obesitas terus meningkat. Organisasi Kesehatan Dunia (WHO) telah mengajak pemerintah di seluruh dunia untuk mencegah peningkatan obesitas pada tahun 2025, dengan tujuan untuk mencegah kematian dini dari empat penyakit tidak menular yang paling umum, seperti penyakit kardiovaskular (jantung dan pembuluh darah), diabetes, kanker, dan penyakit pernapasan kronis (Ansari dkk., 2020)

Di Indonesia, prevalensi obesitas juga semakin meningkat dalam beberapa tahun terakhir. Data Riset Kesehatan Dasar (Riskesdas) 2018 yang diperoleh dari Badan Penelitian dan Pengembangan Kesehatan Kementerian RI (2018) menyatakan obesitas 
pada individu berusia 18 tahun ke atas terus meningkat. Obesitas meningkat dalam tiga periode, yaitu $10,5 \%$ pada tahun 2007 , $14,8 \%$ di tahun 2013 , dan terakhir $21,8 \%$ di tahun 2018. Hasil riset tersebut didapatkan dari 300.000 sampel penduduk dari beberapa wilayah di Indonesia. Dalam hasil Riskesdas 2018 (Badan Penelitian dan Pengembangan Kesehatan Kementerian RI, 2018), ditemukan bahwa Jakarta berada di peringkat kedua tertinggi yang memiliki populasi individu obesitas terbesar, yaitu mendekati angka 30,2\%, kemudian diikuti oleh Jawa Barat di angka mendekati $25 \%$. Populasi obesitas didominasi oleh individu yang berusia 18 tahun ke atas. Indikator obesitas yang dijadikan sampel oleh Riskesdas (Badan Penelitian dan Pengembangan Kesehatan Kementerian RI, 2018) yaitu orang dewasa yang mempunyai body mass index (BMI) di atas 27,0. BMI sering digunakan untuk mengkategorisasikan apakah seseorang mengalami obesitas atau tidak (Deurenberg, Yap, \& Staveren, 1998).

Sandjaja dan Sudikno (2005) menyebutkan kondisi obesitas merupakan keadaan menumpuknya lemak di dalam tubuh seseorang sehingga menyebabkan berat badannya jauh di atas normal. Faktor penyebab obesitas diantaranya adalah status sosial ekonomi, usia, jenis kelamin, faktor keturunan (genetik), konsumsi makanan cepat saji (fast food), faktor keadaan psikologis, kurangnya aktivitas fisik (olahraga), pengaruh iklan di televisi atau media sosial yang memengaruhi pola konsumsi makanan, dan program diet. Beberapa faktor tersebut menyebabkan adanya perubahan keseimbangan energi di dalam tubuh dan berujung pada obesitas (Kurdanti, dkk., 2015). Parental fatness (orang tua yang gemuk) merupakan salah satu faktor genetik yang berperan besar terhadap obesitas pada anak. Apabila kedua orang tua obesitas, maka $80 \%$ anaknya menjadi obesitas. Apabila salah satu orang tua obesitas, kejadian obesitas pada anak menjadi $40 \%$. Sementara itu, jika kedua orang tua tidak obesitas, prevalensi kejadian obesitas pada anak turun menjadi $14 \%$ (Dewi, 2015).

Basuki dan Hartati (2013) mengemukakan bahwa keadaan obesitas berdampak pada kondisi psikososial individu, salah satunya konsekuensi sosial berupa perlakuan yang kurang menyenangkan dari orang lain. Konsekuensi sosial yang dialami individu obesitas dapat berupa diskriminasi dan pemberian stigma negatif di lingkungannya. Pada remaja, keadaan obesitas kerap berdampak pada aspek psikologis individu, diantaranya adalah perasaan bersalah, depresi, kegelisahan, harga diri yang rendah hingga body image yang negatif. Kondisi tersebut dapat memengaruhi kualitas hidup khususnya dalam mobilitas dan daya tahan fisik. Body image negatif dan harga diri yang rendah dapat membuat individu obesitas rentan mengalami bullying (Noer, Kustanti, \& Fitriyanti, 2018). Hal tersebut dapat menyebabkan individu kesulitan dalam pengelolaan berat badan, karena cara mereka menghadapi komentar dan sikap negatif dari lingkungan adalah dengan berdiam diri (Basuki \& Hartati, 2013).

Obesitas dikaitkan dengan beberapa kondisi kesehatan serius, diantaranya yaitu diabetes mellitus tipe 2, penyakit jantung, tekanan darah tinggi (hipertensi), dan stroke (Wellman \& Friedberg, 2002). Menurut Hadi (2004), obesitas juga merupakan salah satu penyebab peningkatan risiko kematian. Individu yang memiliki berat badan sekitar $40 \%$ lebih berat dari berat badan rata-rata populasi, cenderung mempunyai risiko penyakit serta kematian dua kali lebih besar dibandingkan dengan individu yang memiliki berat badan rata-rata (normal). Kenaikan angka kematian pada individu yang mengalami obesitas disebabkan oleh beberapa penyakit serius yang dapat mengancam kehidupan, misalnya diabetes tipe 2, penyakit jantung, penyakit pada kandung kemih, kanker pada organ pencernaan, dan sebagainya. Individu yang mengalami obesitas mempunyai risiko yang lebih besar untuk menderita masalah kesehatan lainnya seperti infertilitas, 
arthritis, back pain, dan fungsi psikososial yang menurun. Banyak studi yang menunjukkan bahwa adanya obesitas berakibat pada kenaikan risiko penyakit dan gangguan lainnya yang dapat muncul pada masa kehidupan berikutnya (Hadi, 2004). Selain penyakit serius, kondisi obesitas juga memengaruhi penampilan fisik individu, seperti adanya timbunan lemak di beberapa bagian tubuh yang dianggap mengurangi keindahan penampilan, atau kesulitan dalam menemukan pakaian yang sesuai dengan kondisi fisiknya (Misnadiarly, 2007).

Salah satu masalah penampilan yang sering terjadi pada individu obesitas adalah bentuk tubuh yang kurang menarik karena adanya penumpukan lemak di beberapa bagian tubuh. Dengan kata lain, individu dianggap gemuk dibandingkan dengan orang lain yang memiliki berat badan normal $(\mathrm{BMI}=18-25)$ (Hasanah, Borualogo, \& Wahyudi, 2017). Faktor penampilan merupakan hal yang menjadi perhatian pada masa dewasa awal. Fokus perhatian terhadap penampilan fisik dimulai ketika individu memasuki usia remaja atau saat individu mulai berusia 20 tahunan (Wardani, 2015). Pada masa ini muncul ketidakpuasan terhadap bentuk dan ukuran tubuh, beberapa orang beranggapan bahwa gemuk merupakan salah satu body image yang negatif dan dapat menimbulkan tekanan psikologis.

Kasus-kasus obesitas di Indonesia yang dikutip oleh Republika.co.id (9 September 2019), salah satunya dialami oleh penyiar radio terkenal yaitu KM. KM mengalami kelebihan berat badan yang mencapai 120 kilogram. Ia mengalami sesak nafas, dan kejadian tersebut sudah terjadi beberapa kali. Dokter mengatakan bahwa jantungnya dalam keadaan normal dan KM disarankan untuk menurunkan berat badannya. Beberapa bulan setelah mengikuti arahan dokter gizi KM berhasil menurunkan berat badannya menjadi 69 kilogram. Selanjutnya, kasus obesitas yang berdampak pada kematian dilansir oleh DetikNews (30/01/2019) dialami oleh SN. Pada awalnya ia mempunyai berat badan 60 kilogram, namun akibat pola makan yang buruk dan tidak teratur, berat badan SN melonjak hingga 148 kilogram. Kondisi obesitas membuat SN kesulitan dalam beraktivitas dan sering mengalami sesak nafas. SN sempat mendapatkan penanganan di rumah sakit, mengikuti program diet dan menjalani operasi bariatrik untuk memperkecil ukuran lambung. Namun demikian, upaya tersebut belum berhasil, akhirnya SN meninggal dunia.

Berdasarkan pemaparan di atas terlihat bahwa kondisi obesitas memiliki dampak serta konsekuensi kesehatan yang negatif seperti penyakit serius hingga kematian pada individu yang mengalaminya. Hal ini yang mendasari penelitian pada individu yang mengalami obesitas. Penelitian terhadap individu obesitas diharapkan dapat menelaah tindakan/upaya apa saja yang dapat dilakukan untuk mengurangi dampak atau konsekuensi negatif akibat obesitas tersebut. Penelitian yang dilakukan oleh Wulansari, Martianto, dan Baliwati (2016), menunjukkan bahwa angka kematian pada individu yang mengalami obesitas semakin meningkat dan membuat produktivitas ekonomi menurun karena meningkatnya kematian dini. Menurut Jayanti dan Burns (1998), terdapat beberapa kategori individu yang memiliki risiko kesehatan, diantaranya: individu yang mengalami obesitas, mengonsumsi minuman beralkohol, merokok, dan individu yang memiliki risiko kesehatan sesuai bertumbuhnya usia. Di Indonesia, berdasarkan data Riskesdas tahun 2018 (Badan Penelitian dan Pengembangan Kesehatan Kementerian RI, 2018), beberapa perilaku berisiko masyarakat yang tergolong dalam Penyakit Tidak Menular (PTM) berkontribusi terhadap disability adjusted life years (DALY) lost pada suatu populasi. Diantara perilaku berisiko tersebut adalah: 1) pola makan tidak sehat (makanan tinggi gula, garam, lemak dan rendah serat). Berdasarkan hasil survei Konsumsi Makanan Individu tahun 2016, secara nasional penduduk Indonesia mengonsumsi gula kategori berisiko (>50 gram per orang 
per hari) sebesar $4,8 \%$, serta mengasup natrium dan lemak kategori berisiko. (> $2.000 \mathrm{mg}$ dan - 14 - $67 \mathrm{~g}$ ); 2) merokok. Prevalensi perokok pada remaja (usia 10-18 tahun) telah naik dari 7,2\% pada tahun 2013 menjadi $9,1 \%$ pada tahun 2018 ; 3) kurangnya aktivitas fisik; 4) obesitas. Obesitas merupakan salah satu faktor risiko yang mendorong munculnya penyakit yang berhubungan dengan faktor metabolik, yaitu penyakit jantung, diabetes, kanker, dan hipertensi (Direktorat Jenderal Pencegahan dan Pengendalian Penyakit Kementerian Kesehatan Republik Indonesia, 2020).

Melihat semakin mengkhawatirkannya faktor risiko penyakit tidak menular, khususnya faktor metabolik dan faktor perilaku, maka diperlukan upaya-upaya strategis untuk mengatasi hal tersebut, diantaranya adalah peningkatan upaya promotif dan preventif serta edukasi kepada masyarakat terkait pencegahan faktor risiko. (Direktorat Jenderal Pencegahan dan Pengendalian Penyakit Kementerian Kesehatan Republik Indonesia, 2020). Individu berisiko tersebut dianjurkan untuk melakukan preventive health care behavior, yang artinya individu dapat menerapkan pola hidup sehat dan melakukan upaya untuk menjaga kesehatan di kehidupan sehari-hari.

Konsekuensi kesehatan yang negatif pada individu obesitas dapat dihindari apabila individu menerapkan preventive health care behavior dalam kehidupan sehari-hari. Pada penelitian yang dilakukan oleh Djaiman, Sari, dan Kusumawardani (2017), disebutkan bahwa individu yang biasa melakukan preventive health care behavior seperti mengonsumsi buah dan sayuran, mengurangi cemilan, serta meningkatkan aktivitas fisik atau berolahraga, memiliki risiko lebih rendah terkena penyakit pada kondisi obesitas. Sebaliknya, individu yang lebih suka mengonsumsi minuman manis, mengonsumsi makanan tinggi lemak dan karbohidrat, mempunyai risiko lebih tinggi terhadap munculnya penyakit dalam kondisi obesitas. Temuan ini sejalan dengan penelitian yang dilakukan oleh Drewnowski, dkk. (1985) bahwa individu obesitas yang tidak menerapkan preventive health care behavior, seperti menyukai dan tetap mengonsumsi makanan mengandung lemak, lebih berisiko terkena penyakit serius dibandingkan individu normal (Drewnowski dkk., 1985). Salah satu bentuk preventive health care behavior adalah tidak mengonsumsi rokok atau mengurangi jumlah konsumsi rokok. Namun demikian, pada beberapa penelitian ditemukan bahwa konsekuensi dari stigma terhadap individu obesitas juga dapat mempengaruhi perilaku merokok. Beberapa perokok, terutama wanita, tidak berusaha untuk berhenti merokok karena mereka takut berat badan bertambah. Merokok berkontribusi pada pengurangan berat badan karena merokok membakar kalori dan adanya kandungan nikotin yang menekan nafsu makan. Beberapa penelitian melaporkan bahwa merokok digunakan sebagai cara untuk menurunkan berat badan, terutama di kalangan perempuan (Chou, Grossman, \& Saffer, 2004; Kim, 2018)

Meskipun individu tersebut mengetahui bahwa tindakan preventive health care behavior dapat mencegah masalah kesehatan serius di masa depan, beberapa diantaranya masih tidak menerapkan perilaku sehat dalam kehidupan sehari-hari (Werle, 2011). Efek yang dapat terjadi ketika seseorang yang memiliki risiko kesehatan tidak melakukan preventive health care behavior adalah risiko terkenanya penyakit akan sangat besar bahkan dapat menyebabkan peristiwa kematian (Wulansari, Martianto, \& Baliwati, 2016). Berdasarkan hal tersebut, peneliti perlu mengetahui gambaran preventive health care behavior pada individu obesitas serta faktor apa yang berperan dalam mendorong tindakan preventive health care behavior, karena hal tersebut merupakan bentuk tindakan pencegahan terhadap risiko kesehatan yang kemungkinan dapat dialami oleh seseorang yang mengalami obesitas.

Preventive health care behavior merupakan perilaku yang akan 
memperpanjang hidup, atau praktik/perilaku yang mengurangi efek penyakit menular, penyakit kronis, atau penyakit yang melemahkan (Jayanti \& Burns, 1998). Preventive health care bahavior termasuk salah satu konsep dalam teori Health Belief Model (HBM). HBM menjelaskan tentang faktor-faktor yang memengaruhi perilaku sehat. Model ini dirancang untuk menjelaskan alasan mengapa seseorang tidak berpartisipasi dalam program pencegahan, dan didasarkan pula pada hipotesis bahwa perilaku pencegahan (preventive behavior) individu dipengaruhi oleh faktor keyakinan seseorang terhadap suatu hal yang berisiko, tingkat keseriusan risiko/tingkat keparahan, adanya cara untuk mengurangi kejadian atau keparahan penyakit, dan biaya yang lebih tinggi dibandingkan manfaat tindakan yang diperoleh. (Dodel \& Mesch, 2017; Shahnazi, dkk., 2020)

Pada evaluasi faktor-faktor di atas, Werle (2011) mengatakan preventive health care behavior berbeda dengan perilaku kesehatan untuk mengobati penyakit yang telah didiagnosis melalui gejala atau pendapat medis. Berdasarkan definisi yang telah dipaparkan, tindakan preventive health care behavior lebih didasarkan pada faktor risiko kesehatan daripada gejala-gejala atau diagnosis formal yang diberikan oleh dokter. Faktor-faktor yang dapat memengaruhi seseorang dalam melakukan preventive health care behavior menurut health belief model (Werle, 2011) adalah kerentanan yang dirasakan pada sebuah risiko kesehatan (health consciousness), persepsi subjektif seseorang tentang risiko penyakit (perceived susceptibility), dan persepsi individu terhadap keseriusan risiko penyakit tertular atau penyakit yang sulit diobati (perceived severity). Keyakinan mengenai efektivitas tindakan preventive health care behavior dapat mengurangi ancaman penyakit di kemudian hari (perceived benefits). Beberapa hambatan yang akan dihadapi oleh individu ketika ingin melakukan suatu tindakan kesehatan (perceived barriers) dan self-efficacy juga berperan dalam meyakinkan seseorang akan adanya potensi masalah kesehatan (Werle, 2011).

Menurut Kraft dan Goodell (1993) preventive health care behavior dapat diwujudkan oleh seseorang yang memiliki kesadaran akan kesehatan (health consciousness). Artinya seseorang yang memiliki kesadaran kesehatan akan cenderung melakukan preventive health care behavior daripada seseorang yang tidak sadar akan kesehatan. Kesadaran kesehatan (health consciousness) merupakan wellnessoriented lifestyle yang berasal dari health belief model (HBM), yaitu sebuah faktor yang memberikan pengaruh signifikan pada perilaku preventive health care behavior dan berkontribusi pada hidup sehat. Kesadaran kesehatan pada setiap individu dapat menentukan bagaimana ia memberikan respon terhadap informasi/isu kesehatan dan mencari tahu mengenai isu kesehatan (Hong, 2009). Kesadaran kesehatan juga merupakan suatu bentuk kesiapan individu untuk melakukan tindakan kesehatan (Becker dkk., 1985), misalnya individu yang tahu bahwa kondisi obesitasnya dapat memunculkan beberapa penyakit biasanya lebih siap dalam mengikuti beberapa tindakan preventive health care behavior. Hal ini diwujudkan demi menjaga kesehatan lebih baik dan panjang, seperti tidak merokok, memiliki diet seimbang yang kaya sayuran dan buahbuahan, berolahraga secara teratur, menghindari minuman keras, dan rutin memeriksakan kondisi kesehatan ke ahli medis (Werle, 2011),

Berdasarkan penelitian sebelumnya (Kraft \& Goodell, 1993; Jayanti \& Burns, 1998; Hong, 2009; Werle, 2011) diketahui bahwa terdapat hubungan langsung antara kesadaran kesehatan dan preventive health care behavior. Sedangkan pada individu yang mengalami obesitas, Willet (2002) menyebutkan bahwa keinginan seorang individu untuk menghindari lemak makanan dan keinginan untuk menjadi kurus sangat terkait dengan kesadaran kesehatan (health consciousness) dalam dirinya. Adanya kesadaran kesehatan dapat mendorong serta 
memotivasi seseorang untuk melakukan preventive health care behavior dengan cara menerapkan perilaku hidup sehat (Gould, 1988). Jika individu obesitas memiliki kesadaran kesehatan, maka individu tersebut menyadari akan kesehatannya dan segera menerapkan preventive health care behavior seperti menurunkan berat badan dan dapat mencari informasi kesehatan terkait faktor apa saja yang akan memengaruhi penurunan berat badannya, misalnya melakukan diet dan meningkatkan aktivitas fisik (Azkia \& Wahyono, 2018; Sari, Ernalia \& Bebasari, 2017).

Michaelidou dan Hassan (2008) mengemukakan bahwa individu yang memiliki kesadaran kesehatan dan prihatin tentang kesehatannya cenderung termotivasi untuk meningkatkan atau menjaga kesehatan mereka, serta meningkatkan kualitas hidup untuk mencegah kesehatan yang buruk dengan cara terlibat dalam perilaku sehat dan menjadi sadar diri terhadap kesehatan. Untuk meningkatkan konsistensi antara kesadaran kesehatan dengan perilaku individu menuju ke arah preventive health care behavior, diperlukan adanya peringatan yang konsisten untuk mengingatkan individu tersebut berpikir dan bertanggung jawab terhadap kesehatannya melalui media informasi (Kutresnaningdian \& Albari, 2012). Berdasarkan hal tersebut dapat disimpulkan bahwa kesadaran kesehatan akan memotivasi seseorang untuk melakukan perilaku sehat yang merupakan bentuk dari preventive health care behavior (Gould, 1988).

Keberadaan kesadaran kesehatan diharapkan dapat mendorong individu yang mengalami obesitas untuk melakukan tindakan preventive health care behavior, demi meminimalkan risiko terjadinya penyakit yang berbahaya di kemudian hari. Sebagaimana diketahui bahwa berdasarkan data yang telah dipaparkan sebelumnya jumlah penderita obesitas semakin meningkat akibat pola hidup yang tidak sehat. Pada penelitian ini, peneliti ingin melihat lebih lanjut terkait seberapa signifikan dan besarnya peran kesadaran kesehatan terhadap preventive health care behavior pada dewasa awal yang mengalami obesitas. Penelitian sebelumnya pada individu yang mengalami obesitas umumnya mengukur variabel self-esteem, aktivitas fisik, pola makan, dan body image (Mustikawati \& Pudjiastuti, 2017; Azkia \& Wahyono, 2018; Sari, Ernalia, \& Bebasari, 2017; Noer, Kustanti, \& Fitriyanti, 2018). Sementara itu penelitian terkait dengan kesadaran kesehatan dan perannya terhadap preventive health care behavior pada individu yang mengalami obesitas belum banyak ditemukan di Indonesia. Penelitian mengenai variabel kesadaran kesehatan yang dilakukan terkait dengan konsumsi makanan organik (Kutresnaningdian \& Albari, 2012) sedangkan preventive health care behavior umumnya ditemukan pada variabel penyakit serius seperti pencegahan osteoporosis, HIV, penyakit jantung (Rajaratenam, dkk., 2014; Kambu, dkk., 2016; Indrawati, 2014), padahal kesadaran kesehatan merupakan variabel yang berhubungan langsung dengan preventive health care behavior (Jayanti \& Burns, 1998; Hong, 2009). Kedua variabel tersebut diprediksi akan memengaruhi kesehatan pada individu obesitas, yang berdampak pada upaya pencegahan risiko kematian akibat obesitas. Berdasarkan hal tersebut, peneliti menduga bahwa kesadaran kesehatan memiliki peran yang signifikan dalam mendorong upaya preventive health care behavior pada individu yang mengalami obesitas. Oleh sebab itu, hipotesis penelitian ini adalah: kesadaran kesehatan berperan secara signifikan terhadap preventive health care behavior pada individu dewasa awal yang mengalami obesitas.

\section{METODE PENELITIAN Pendekatan}

Penelitian ini menggunakan metode penelitian kuantitatif untuk menguji teori objektif dengan memeriksa hubungan antar variabel (Creswell, 2014), dengan rancangan penelitian cross sectional. Tipe penelitian yang dipakai adalah penelitian korelasional 
yang dimaksudkan untuk mengetahui ada atau tidak adanya hubungan antara dua atau beberapa variable (Arikunto, 2010). Pada teknik pengumpulan data, peneliti menggunakan skala sebagai instrumen penelitian.

\section{Variabel Penelitian}

Pada penelitian ini terdapat dua variabel, yaitu variabel prediktor dan variabel kriteria. Variabel prediktor pada penelitian ini adalah kesadaran kesehatan dan variabel kriteria adalah preventive health care behavior. Kesadaran kesehatan adalah suatu kesadaran yang dimiliki individu untuk peduli dan lebih memperhatikan kesehatannya, untuk menjadi lebih baik, dan termotivasi dalam memperbaiki, mempertahankan, dan menjaga kesehatan (Michaelidou \& Hassan, 2008). Sementara itu, preventive health care behavior merupakan perilaku yang akan memperpanjang hidup atau praktik/perilaku yang mengurangi efek penyakit menular, penyakit kronis, atau penyakit yang melemahkan (Jayanti \& Burns, 1998).

Variabel preventive health care behavior diukur menggunakan Preventive Health Care Behavior Scale (PHCB Scale). PHCB scale merupakan alat ukur unidimensi yang diadaptasi oleh Jayanti dan Burns (1998). Alat ukur tersebut merupakan hasil modifikasi dari alat ukur health behaviors yang dikembangkan oleh Moorman dan Matulich (1993) yang terdiri dari beberapa dimensi yaitu positive diet, prointeract, negative diet, bcontrol, life balance, alcohol dan tobacco. Alat ukur ini memiliki nilai reliabilitas yang baik $(0,81)$, jumlah aitem pada alat ukur adalah 17 aitem yang menggambarkan perilaku individu untuk memelihara/menjaga kesehatannya. dan telah digunakan pada beberapa penelitian untuk mengukur variabel preventive health care behavior. Pada PHCB scale, semakin tinggi nilai total skor yang diperoleh individu maka semakin besar kecenderungan individu tersebut melakukan tindakan preventive health care behavior. Kesadaran kesehatan diukur menggunakan health consciousness scale (HC scale), yang merupakan skala unidimensional (Michaelidou \& Hassan, 2008; Hong, 2011). Dimensi skala kesadaran kesehatan yaitu health self-consciousness, health alertness, health involvement, health self-monitoring, dengan total jumlah aitem adalah enam aitem. Semakin tinggi nilai total skor maka semakin besar kecenderungan individu tersebut untuk sadar akan kesehatannya (Jayanti \& Burns, 1998; Michaelidou \& Hassan, 2008; Hong, 2011).

\section{Partisipan}

Partisipan penelitian adalah individu usia dewasa awal dan mengalami obesitas. Pengambilan sampel dilakukan sedemikian rupa sehingga diperoleh sampel yang dapat menggambarkan keadaaan populasi yang sebenarnya atau representatif (Sugiyono, 2016). Sampel mempunyai kriteria tertentu, yaitu individu dewasa awal berusia $20-40$ tahun. Karakteristik lainnya adalah dewasa awal yang mengalami obesitas atau BMI $>27$.

Teknik pengambilan sampel adalah non probability sampling dengan metode accidental sampling. Pengambilan sampel penelitian dilakukan secara online melalui google form, pada bulan SeptemberNopember 2020. Metode yang digunakan dalam penelitian ini adalah tryout terpakai. Hal ini disebabkan karena terbatasnya ruang dan waktu di masa pandemi COVID-19 serta karakteristik sampel yang sulit dijangkau, sehingga peneliti hanya melakukan satu kali pengambilan data. Data tersebut akan diuji reliabilitas dan validitasnya, serta dilakukan uji data penelitian dengan bantuan program SPSS. Peneliti mencantumkan link kalkulator BMI serta rumus BMI di awal pengisian formulir, kemudian partisipan diminta untuk menuliskan BMI mereka di pengisian data diri.

\section{Instrumen}

Instrumen yang digunakan pada penelitian ini adalah Health Consciousness Scale (HCS) dengan reliabilitas 0,7, dikembangkan oleh Michaelidou \& Hassan 
(2008) yang diadaptasi dari Gould (1988). HCS menggunakan skala nol (sangat tidak setuju) sampai enam (sangat setuju). Nilai yang lebih tinggi menunjukkan bahwa indvidu memiliki kesadaran yang lebih besar tentang kesehatan. Alat ukur kedua adalah preventive behavior scale (PBS) dengan reliabilitas 0,81 , dipublikasikan oleh Jayanti dan Burns (1998) dan merupakan adaptasi dari alat ukur health behaviors yang dikembangkan oleh Moorman dan Matulich pada tahun 1993. Menggunakan tujuh skala poin, yaitu: tidak pernah (1) sampai selalu (3), dengan pertanyaan utama: Seberapa sering Anda melakukan kegiatan berikut?

Tabel 1

Blue Print Alat Ukur Preventive Health Care Behavior

\begin{tabular}{|c|c|c|}
\hline Dimensi & $\begin{array}{l}\text { Jumlah } \\
\text { Aitem }\end{array}$ & Contoh Aitem \\
\hline $\begin{array}{l}\text { Positive diet } \\
\text { (Mengonsumsi zat yang berguna bagi tubuh) }\end{array}$ & 2 & Makan makanan yang seimbang \\
\hline $\begin{array}{l}\text { Prointeract } \\
\text { (Menemui ahli kesehatan) }\end{array}$ & 2 & $\begin{array}{l}\text { Menemui dokter gigi untuk } \\
\text { pemeriksaan rutin }\end{array}$ \\
\hline $\begin{array}{l}\text { Negative diet } \\
\text { (Pengurangan zat yang dapat menimbulkan efek } \\
\text { negatif bagi tubuh jika dikonsumsi secara } \\
\text { berlebihan) }\end{array}$ & 6 & $\begin{array}{l}\text { Mengurangi jumlah garam dalam } \\
\text { diet }\end{array}$ \\
\hline $\begin{array}{l}\text { Bcontrol } \\
\text { (Mengontrol jumlah zat atau makanan yang } \\
\text { dikonsumsi) }\end{array}$ & 2 & $\begin{array}{l}\text { Memperhatikan jumlah daging } \\
\text { merah yang anda makan }\end{array}$ \\
\hline $\begin{array}{l}\text { Life balance } \\
\text { (membagi waktunya kapan ia akan beraktivitas } \\
\text { dan kapan ia akan beristirahat) }\end{array}$ & 3 & Mengurangi stres dan kecemasan \\
\hline Alcohol & 1 & $\begin{array}{l}\text { Memperhatikan jumlah alkohol } \\
\text { yang anda minum }\end{array}$ \\
\hline Tobacco & 1 & $\begin{array}{l}\text { Mencoba untuk menghindari } \\
\text { merokok }\end{array}$ \\
\hline Total & 17 & - \\
\hline
\end{tabular}

Tabel 2

Blue Print Alat Ukur Health Consciousness

\begin{tabular}{lccc}
\hline \multicolumn{1}{c}{ Dimensi } & $\begin{array}{c}\text { Jumlah } \\
\text { Aitem }\end{array}$ & \multicolumn{2}{c}{ Contoh Aitem } \\
\hline $\begin{array}{l}\text { Health self-consciousness } \\
\text { (Kesadaran individu terhadap kondisi kesehatannya) }\end{array}$ & 2 & $\begin{array}{c}\text { Saya banyak berfikir tentang } \\
\text { kesehatan saya }\end{array}$ \\
\hline $\begin{array}{l}\text { Health alertness } \\
\text { (Kewaspadan terhadap kondisi kesehatan individu) }\end{array}$ & 2 & $\begin{array}{l}\text { Saya biasanya } \\
\text { kesehatan saya }\end{array}$ \\
\hline $\begin{array}{l}\text { Health } \text { involvement } \\
\text { (Bertanggung jawab terhadap kondisi kesehatannya) }\end{array}$ & 1 & $\begin{array}{l}\text { Saya bertanggung jawab atas } \\
\text { keadaan kesehatan saya }\end{array}$ \\
\hline $\begin{array}{l}\text { Health self-monitoring } \\
\text { (Kemampuan individu untuk dapat memantau } \\
\text { dirinya sendiri dan lingkungan sekitarnya) }\end{array}$ & 1 & $\begin{array}{l}\text { Dalam keseharian saya, saya } \\
\text { menyadari kondisi kesehatan saya }\end{array}$ \\
\hline \multicolumn{1}{c}{ Total } & 6 & & -
\end{tabular}

Penelitian ini menggunakan dua alat ukur yaitu PHCB scale yang dikembangkan oleh Jayanti dan Burns (1998) dan HC scale yang dikembangkan oleh Michaelidou dan Hassan (2008). Kedua alat ukur tersebut berbahasa Inggris. Sebelum menggunakan 
PHCB scale dan HC scale di penelitian ini, peneliti melakukan translasi alat ukur ke Bahasa Indonesia. Peneliti meminta bantuan dua orang penerjemah yang sudah bersertifikasi dan berpengalaman untuk melakukan translate yaitu dari Bahasa Inggris ke Bahasa Indonesia dan back translate dari Bahasa Indonesia ke Bahasa Inggris. Proses expert judgement pada penelitian ini dilakukan dengan cara mengajukan kedua alat ukur yang sudah melalui proses forward translate dan back translate kepada Lembaga Pusat Penelitian Pengembangan dan Terapan Psikologi Kesehatan (P3TPK) Universitas YARSI. Expert judgement dilakukan pada kedua alat ukur yang digunakan yaitu HBS dan HCS. Expert judgment untuk masing-masing alat ukur dilakukan oleh dua ahli. Tujuannya agar alat ukur yang akan dipakai dalam penelitian jelas dan dapat dimengerti oleh subjek penelitian, baik secara instruksi pengisian ataupun kalimat aitem pada alat ukur tersebut. Hasil expert judgement dalam penelitian ini adalah adanya feedback mengenai pilihan kata dan susunan kalimat aitem agar dapat lebih dimengerti oleh partisipan. Setelah dilakukannya expert judgement peneliti melakukan uji keterbacaan alat ukur pada subjek yang memiliki karakteristik yang sama dengan subjek penelitian. Uji keterbacaan pada penelitian ini dilakukan dengan cara memberikan kedua alat ukur untuk diuji kepada tiga partisipan. Partisipan tersebut adalah individu yang mengalami obesitas dan berusia 20 tahun, 23, dan 39 tahun. Berdasarkan hasil uji keterbacaan, ketiga pertisipan dapat memahami aitem-aitem di dalam alat ukur HC dan PHCB. Alat ukur PHCB yang dipublikasi oleh Jayanti dan Burns (1998) merupakan adaptasi dari alat ukur health behaviors yang dikembangkan oleh Moorman \& Matulich pada tahun 1993. Validasi alat ukur ini menggunakan teknik discriminant validity. Sedangkan alat ukur HC menggunakan skala yang dibuat dan dipublikasikan oleh Michaelidou dan
Hassan (2008) yang diadaptasi dari Gould (1988). Validitas yang digunakan Michaelidou dan Hassan (2008) adalah validitas konstruk yaitu exploratory factor analysis. Dalam penelitian sebelumnya kedua alat ukur ini valid untuk mengukur variabel apa yang akan diukur.

Dalam penelitian ini peneliti menggunakan validitas konten dan validitas konstruk. Dalam melakukan validasi konten, peneliti melibatkan dua ahli. Pengujian validitas ini menggunakan pendapat para ahli dengan menelaah isi tiap butir alat ukur apakah sesuai dengan tujuan pengukurannya atau tidak. Validitas konstruk dilakukan dengan menganalisis interkorelasi antar aitem di dalam suatu alat ukur.

Pada penelitian Jayanti dan Burns (1998), uji reliabilitas PBS menggunakan uji test-retest reliability dan diperoleh $\mathrm{r}$ sebesar 0,81. Sedangkan untuk HCS, uji reliabilitas menggunakan reliabilitas Cronbach's Alpha. Nilai alpha semuanya di atas tingkat yang disarankan yaitu 0,7. Alat ukur yang digunakan dalam penelitian ini merupakan hasil dari proses adaptasi alat ukur. Sehingga untuk dapat menggunakan alat ukur tersebut peneliti menguji kembali tingkat reliabilitas (Cronbach's Alpha) kedua alat ukur. Berdasarkan hasil uji reliabilitas terhadap data tryout dalam penelitian ini, PBS memperoleh reliabilitas Cronbach's Alpha sebesar $\alpha=0,886$, sedangkan reliabilitas HCS sebesar $\alpha=0,880$.

Analisis aitem adalah suatu proses untuk menguji respon subjek penelitian terhadap aitem yang dibuat yang bertujuan untuk melihat dan menilai kualitas dari aitem-aitem dan secara keseluruhan. Analisis aitem dapat melihat manakah aitem yang ambigu, menyesatkan dan tidak relevan yang nantinya aitem tersebut akan dieliminasi (Widhiarso, 2010). Berdasarkan analisis aitem yang dilakukan oleh peneliti, diperoleh rentang skor pada PBS, sperti yang tertera pada tabel 3 . 
Tabel 3

Skor Correlated Item Total PBS

\begin{tabular}{ccc}
\hline $\begin{array}{c}\text { Cronbach } \\
\text { Alpha }\end{array}$ & Correlated item total & $\mathrm{N}$ \\
\hline 0,886 & $0,204-0,684$ & 6 \\
\hline
\end{tabular}

Rentang analisis aitem pada PBS jika dilihat dari correlated item total sebesar $0,204-0,684$, berdasarkan rentang skor seluruh aitem pada PHCB scale dapat digunakan dalam penelitian ini, hal tersebut mengacu pada nilai validitas menurut Agustia dkk. (2020) dapat dikatakan sesuai dan baik jika nilai corrected item dari total correlation dengan nilai di atas 0,20.

Tabel 1

Skor Correlated item total HCS

\begin{tabular}{ccc}
\hline $\begin{array}{c}\text { Cronbach } \\
\text { Alpha }\end{array}$ & $\begin{array}{c}\text { Correlated item } \\
\text { total }\end{array}$ & $\mathrm{N}$ \\
\hline 0,880 & $0,607-0,795$ & 17 \\
\hline
\end{tabular}

Pada HCS, rentang correlated item total yang didapatkan sebesar 0,607-0,795. Hal ini menunjukan bahwa skor $>0,20$, maka seluruh aitem HCS layak untuk digunakan dalam penelitian ini.

\section{Teknik Analisis Data}

Teknik analisis data dalam penelitian ini menggunakan bantuan aplikasi SPSS Statistics 26. Analisis statistik yang dilakukan adalah uji normalitas, uji linieritas, dan uji regresi. Uji normalitas adalah pengujian data untuk melihat apakah nilai residual terdistribusi normal atau tidak (Ghazali, 2011). Pada penelitian ini digunakan uji satu sampel KolmogorovSmirnov untuk menguji normalitas model regresi (Ghozali, 2011). Apabila suatu variabel lebih besar dari level of significant $5 \%(>0,050)$ maka variabel tersebut terdistribusi normal, sedangkan jika nilai Asymp. Sig. suatu variabel lebih kecil dari level of significant $5 \%(<0,050)$ maka variabel tersebut tidak terdistribusi normal (Cresswell, 2012). Uji linearitas dilakukan untuk melihat apakah variabel bebas dan variabel terikat memiliki hubungan yang linear atau garis lurus (Sugiyono, 2013).
Salah satu syarat untuk pengujian regresi adalah uji linearitas, artinya jika hasil uji ini tidak menunjukkan linear maka analisis regresi tidak dapat digunakan. Nilai sig (p) dengan ketentuan bila $\mathrm{p}<0,05$ adalah liniear, sedangkan bila data memiliki nilai $\mathrm{p}>0,05$ artinya data tersebut tidak linear.

Uji korelasi pada penelitian ini menggunakan Pearson Product Moment, apabila nilai Sig. (2-tailed) $<0,05$, maka hubungan yang terdapat pada nilai $r$ dianggap signifikan. Uji hipotesis pada penelitian ini adalah regresi linear sederhana. Menurut Harlan (2018), regresi linear (linear regression) adalah teknik yang digunakan untuk memperoleh model hubungan antara satu variabel dependen dengan satu atau lebih variabel independen. Jika hanya digunakan satu variabel independen dalam model, maka teknik ini disebut sebagai regresi linear sederhana (simple linear regression). Penelitian ini menggunakan satu variabel dependen/ kriteria yaitu preventive health care behavior, dan satu variabel independen /prediktor yaitu health consciousness. Untuk persamaan regresi sederhana adalah: 
$\mathbf{Y}=\mathbf{a}+\boldsymbol{\beta} \mathbf{X}+\mathbf{e}$.

Keterangan:

$\mathrm{X}=$ Health Consciousness

$\beta=$ Nilai Koefisien Regresi

$\mathrm{Y}=$ Preventive Health Care Behavior

$\mathrm{e}=$ Kemungkinan eror yang akan terjadi

$\mathrm{a}=$ Nilai Konstanta

\section{ANALISIS DAN HASIL}

Partisipan penelitian terdiri dari 82 orang. Penelitian dilakukan dengan tujuan untuk melihat seberapa signifikan peran kesadaran kesehatan terhadap preventive health care behavior pada individu yang mengalami obesitas. Kriteria subjek adalah individu usia dewasa awal yaitu 20 - 40 tahun dan mengalami obesitas (skor BMI $\geq 27$ ). Kondisi pandemi virus COVID-19 membuat peneliti tidak dapat melakukan pengambilan data secara langsung/tatap muka, sehingga pengambilan data pada penelitian ini dilakukan secara daring (online) melalui media sosial seperti Instagram, Twitter, Line dan WhatsApp.

Berdasarkan Tabel 5, sampel yang didapatkan sebanyak 82 partisipan, yang tersebar di wilayah JABODETABEK. Mayoritas partisipan berpendidikan akhir SMA dan S1 (sarjana). Partisipan penelitian memiliki komposisi yang seimbang bila ditinjau dari jenis kelamin, yaitu 51,22\% laki-laki dan 48,78\% perempuan. Sedangkan untuk skor BMI partisipan berada pada rentang 27,1 - 69 dengan rata-rata BMI yang didapatkan dari seluruh partisipan 31,5.

Tabel 5

Data Demografi

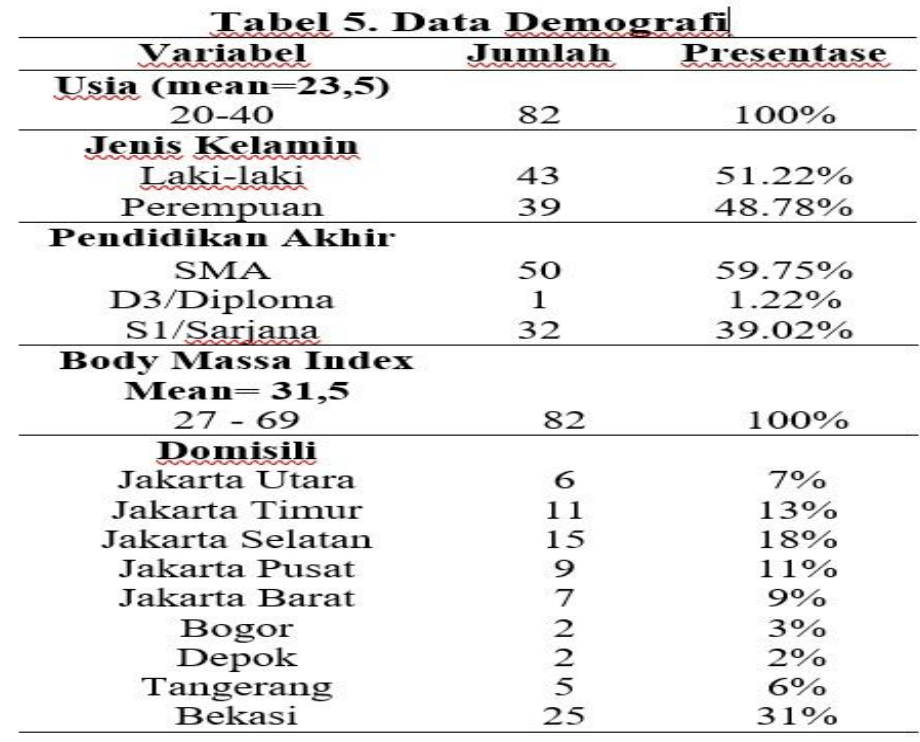

\section{Hasil Penelitian}

Pengukuran kesadaran kesehatan menggunakan enam aitem dengan skor

terendah 0 dan skor tertinggi 6 . Kemungkinan skor tertinggi adalah 36 dan 
skor terendah adalah 0 dengan mean hipotetik 17. Berdasarkan hasil sebaran kuesioner diperoleh nilai maksimum sebesar 36 dan nilai minimum sebesar 13 dengan mean 27,963. Pengukuran variabel preventive health care behavior menggunakan 17 aitem dengan skor terendah satu dan skor tertinggi tiga. Dengan demikian, kemungkinan skor tertinggi adalah 51 dan skor terendah adalah 17 dengan mean hipotetik 34. Berdasarkan hasil sebaran kuesioner diperoleh nilai maksimum sebesar 51 dan nilai minimum sebesar 20 dengan mean 36,402 .

Tabel 6

Deskripsi Statistik Variabel Penelitian

\begin{tabular}{lccc}
\hline Variabel & & Hipotetik & \\
\hline & Min & Max & Mean \\
\hline $\begin{array}{l}\text { Health } \\
\text { Consciousness }\end{array}$ & 0 & 36 & 17 \\
\hline $\begin{array}{l}\text { Preventive } \\
\text { Health Care } \\
\text { Behavior }\end{array}$ & 17 & 51 & 34 \\
\hline
\end{tabular}

Tabel 7

Deskripsi Statistik Variabel Penelitian

\begin{tabular}{lcc}
\hline & $\begin{array}{c}\text { Health } \\
\text { Consciousness }\end{array}$ & $\begin{array}{c}\text { Preventive Health } \\
\text { Care Behavior }\end{array}$ \\
\hline Mean & 27,963 & 36,402 \\
Std. & 6,009 & 6,829 \\
Deviation & 13 & 20 \\
Minimum & 36 & 51 \\
Maximum & & \\
\hline
\end{tabular}

Kategorisasi data dalam penelitian ini menggunakan rumus dari Azwar (2010), yang menjelaskan bahwa tujuan dari kategorisasi data adalah untuk menempatkan individu ke dalam kelompok yang terpisah secara berjenjang berdasarkan atribut yang diukur. 
Tabel 8

Kategorisasi Data Preventive Health Care Behavior

\begin{tabular}{cccc}
\hline Kategori & Kriteria & Frekuensi & Presentase \\
\hline Tinggi & $>39,6$ & 31 & $37,8 \%$ \\
Sedang & $28,4<\mathrm{X}<39,6$ & 41 & $50 \%$ \\
Rendah & $<28,4$ & 10 & $12,2 \%$ \\
\hline Total & & & $100 \%$ \\
\hline
\end{tabular}

Berdasarkan kategorisasi pada Tabel 8, diketahui bahwa hasil kategorisasi data menunjukan kategori tinggi yaitu sebesar $37,8 \%$ atau 31 responden. Sedangkan pada kategori sedang menunjukan presentase
$50 \%$ atau setengah dari keseluruhan partisipan yaitu 41 orang, kemudian untuk kategori rendah menunjukan $12,2 \%$ yaitu 10 dari 82 partisipan.

Tabel 9

Kategorisasi Data Kesadaran Kesehatan

\begin{tabular}{cccc}
\hline Kategori & Kriteria & $\begin{array}{c}\text { Frekuen } \\
\text { si }\end{array}$ & Presentase \\
\hline Tinggi & $>23$ & 66 & $80,5 \%$ \\
Sedang & $11<\mathrm{X}<23$ & 16 & $19,5 \%$ \\
Rendah & $<11$ & - & - \\
\hline Total & & 82 & $100 \%$ \\
\hline
\end{tabular}

Berdasarkan kategorisasi pada Tabel 9, diketahui bahwa hasil kategorisasi data dengan mean hipotetik menunjukan kategori tinggi sebesar $80,5 \%$ yaitu sebanyak 66 dari 82 partisipan. Sedangkan pada kategori sedang menunjukan $19,5 \%$ dengan 16 partisipan.

\section{Uji Asumsi : Uji Normalitas dan Uji Linearitas}

Pada awal pengujian uji normalitas, peneliti menggunakan pendekatan asymptotic dan hasil menunjukan bahwa data tidak terdistribusi normal yaitu dengan signifikasi sebesar 0.000. Kemudian peneliti melihat apakah terdapat outliers di dalam sebaran data penelitian, dan hasil menunjukan tidak ada outliers dalam sebaran data. Langkah selanjutnya peneliti melakukan transformasi data, namun hasil transformasi tersebut tidak membuat data terdistribusi normal. Menurut Mehta dan
Nitin (2011), pada metode pendekatan asymptotic di dalam SPSS nilai $\mathrm{p}$ diasumsikan bahwa data dengan ukuran sampel yang cukup besar, sesuai dengan distribusi tertentu. Namun demikian, jika kumpulan data kecil, jarang, berisi banyak ikatan, tidak seimbang, atau tidak terdistribusi dengan baik, metode asymptotic mungkin gagal memberikan hasil yang diharapkan. Dalam kondisi ini, untuk menghitung tingkat signifikansi pada uji normalitas, dengan menggunakan pendekatan exact adalah cara yang tepat. Berdasarkan uji normalitas terhadap kedua variabel dengan menggunakan metode pendekatan exact melalui program SPSS ditemukan bahwa variable kesadaran kesehatan dan preventive health care behavior terdistribusi normal dengan nilai signifikansi 0,55 , hal ini melebihi nilai signifikansi seharusnya yaitu $\mathrm{p}>0,05$. Pada uji linearitas, ditemukan nilai signifikansi 
sebesar 0,001 $(\mathrm{p}<0,05)$, sehingga dapat disimpulkan bahwa terdapat hubungan linier dan signifikan antara kesadaran kesehatan dengan preventive health care behavior.

\section{Uji Korelasi dan Uji Regresi Linear Sederhana}

Hasil uji korelasi menggunakan Spearman menunjukkan bahwa kesadaran kesehatan berkorelasi positif dengan preventive health care behavior, dengan arah hubungan yang positif, dan tingkat korelasi cukup ( $\left.\mathrm{r}=-.460^{* *}, \quad \mathrm{Sig}=0,000\right)$, Artinya, semakin tinggi kesadaran kesehatan, maka semakin tinggi tindakan preventive health care behavior.

Tabel 10

Uji Korelasi

\begin{tabular}{|c|c|c|c|}
\hline & & $\begin{array}{l}\text { Preventive Health } \\
\text { Care Behavior }\end{array}$ & $\begin{array}{c}\text { Health } \\
\text { Consciousne } \\
\text { ss }\end{array}$ \\
\hline Preventive Health & Pearson & 1 & $.468^{* *}$ \\
\hline Care Behavior & Correlation & & \\
\hline & Sig. (2-tailed) & & .000 \\
\hline Health & Pearson & $.468^{* *}$ & 1 \\
\hline Consciousness & Correlation & & \\
\hline & Sig. (2-tailed) & .000 & \\
\hline
\end{tabular}

Tabel 11

Uji Regresi Linear

\begin{tabular}{lcccccc}
\hline & $\mathbf{R}$ & $\mathbf{R}^{2}$ & $\mathbf{B}$ & Std. Error & $\mathbf{t}$ & $\mathbf{p}$ \\
\hline & .468 & .219 & & & & \\
Health & & & 21.515 & 3.210 & 6.703 & .000 \\
Consciousness & & & .532 & .112 & 4.743 & .000 \\
\hline
\end{tabular}

Berdasarkan hasil uji regresi ditemukan bahwa variabel kesadaran kesehatan memiliki peran yang signifikan terhadap preventive health care behavior, yaitu sebesar $21,9 \%\left(\mathrm{p} .000, \mathrm{R}^{2}=.219\right)$, sedangkan sisanya yaitu $78,1 \%$ dipengaruhi oleh variabel lain. Berdasarkan tabel 11 diperoleh nilai constant (a) sebesar 21,515, sedangkan nilai kesadaran kesadaran (b/koefisien regresi) sebesar 0,532. Hasil tersebut dimasukkan dalam persamaan regresinya sebagai berikut:

$$
Y=21,515+0,532 X+3,210
$$




\section{DISKUSI}

Berdasarkan hasil uji analisis data penelitian dengan menggunakan uji regresi linear, diketahui bahwa kesadaran kesehatan memiliki peran yang signifikan terhadap preventive health care behavior ( $\mathrm{p} .000, \mathrm{R} 2$ $=.219$ ). Hal ini mengindikasikan bahwa kesadaran kesehatan pada individu yang mengalami obesitas berperan secara signifikan terhadap preventive health care behavior dengan kontribusi sebesar 21,9\%. Sementara itu sekitar $78,1 \%$ dipengaruhi oleh faktor lain diantaranya health motivation, health knowledge (Jayanti \& Burns, 1998), perceived susceptibility, perceived severity, perceived benefits, perceived barriers, self-efficacy (Werle, 2011). Dengan demikian, Ha dalam penelitian ini diterima.

Iversen dan Kraft (2006) menyebutkan bahwa kesadaran kesehatan merupakan status psikologis atau batin seseorang. Kondisi ini termasuk diantaranya: kewaspadaan akan kesehatan, kesadaran diri terkait kesehatan, keterlibatan diri terhadap kesehatan, dan pemantauan diri terhadap kesehatan seseorang. Individu yang sadar akan kesehatannya dan menyadari bahwa adanya risiko yang akan datang dikemudian hari, akan mencari dan menggunakan informasi kesehatan dari berbagai sumber dalam melakukan suatu tindakan preventive health care behavior dan lebih aktif dalam perilaku mempromosikan kesehatan (Rodgers dkk. dalam Hong, 2009). Pentingnya peranan kesadaran kesehatan dalam mendorong preventive health care behavior juga dijelaskan oleh Gould (dalam Hoque, Alam, \& Nahid, 2018) yang membagi kesadaran kesehatan menjadi empat dimensi yaitu perhatian yang lebih besar terhadap kesehatan, peduli tentang kesehatan, terlibat dalam pencarian informasi kesehatan, dan menghargai kondisi kesehatan. Untuk menjaga kesehatan yang dimilikinya, individu dapat menerapkan suatu tindakan preventive health care behavior seperti pola makan yang baik, melakukan diet sehat, meningkatkan aktivitas fisik (olahraga yang teratur) dan sebagainya.

Pada penelitian yang dilakukan Moorman dan Maulich (1993), telah dijelaskan lebih lanjut terkait dimensi yang dapat mendukung apakah seorang individu tersebut sudah menerapkan tindakan preventive health care behavior, diantaranya memperoleh informasi kesehatan dari berbagai media dan label makanan. Selain memperoleh informasi dari media atau produk makanan, informasi kesehatan juga dapat diperoleh dari lingkungan sekitar seperti teman, keluarga ataupun tenaga medis. Hal tersebut dapat meningkatkan pengetahuan seseorang terkait kesehatan (health knowledge) sehingga individu sadar akan kesehatannya yang harus selalu dijaga (Hong, 2009). Adanya pengetahuan tentang kesehatan seperti cara memelihara kesehatan sampai risiko kesehatan membuat individu harus menyeimbangkan hidupnya dengan membagi waktu untuk beraktivitas dan beristirahat. Menurut Moorman dan Matulich (1993) hal yang dapat mendukung perilaku preventive health care behavior yaitu menerapkan gaya hidup sehat dengan diet positif, seperti memperbanyak konsumsi sayuran dan buah, diet negatif seperti mengurangi konsumsi gula dan garam yang berlebih, mengurangi konsumsi alkohol dan tidak rokok.

Kesadaran kesehatan erat kaitannya dalam menentukan respons seseorang terhadap informasi kesehatan, karena hal ini merupakan kecenderungan internal dalam diri seseorang untuk melakukan suatu tindakan seperti preventive health care behavior (Lazarfield, dalam Suchman, 1967). Kutresnaningdian dan Albari (2012) dalam penelitiannya mengatakan bahwa untuk meningkatkan konsistensi antara kesadaran kesehatan dengan perilaku individu menuju ke arah preventive health care behavior, diperlukan adanya peringatan yang konsisten untuk mengingatkan individu tersebut berpikir dan bertanggung jawab terhadap kesehatannya. Misalnya, dengan adanya peringatan risiko kesehatan melalui media massa, hal tersebut dapat 
mempengaruhi seseorang untuk sadar akan kondisi kesehatannya (health consciousness) dan lebih memperhatikan kesehatannya, kemudian melakukan evaluasi apakah kondisi kesehatannya terancam atau tidak (Mulyana, 2002). Ketika ia sadar akan kondisi kesehatannya terancam maka individu tersebut terdorong untuk melakukan suatu tindakan pencegahan atau preventive health care behavior (Mulyana, 2002). Werle (2011) menyebutkan bahwa preventive health care behavior dapat dipengaruhi oleh kerentanan yang dirasakan seseorang pada sebuah risiko kesehatan yang dapat membuatnya sadar (health consciousness), hal ini membuat individu yakin bahwa tindakan preventive health care behavior dapat mengurangi ancaman penyakit di kemudian hari (perceived benefits). Menurut Kraft dan Goodell (1993) preventive health care behavior dapat diwujudkan oleh seseorang yang memiliki kesadaran akan kesehatan (health consciousness), artinya seseorang yang memiliki kesadaran kesehatan akan cenderung melakukan preventive health care behavior daripada seseorang yang tidak sadar akan kesehatan.

Pada individu yang mengalami obesitas, Willet (2002) menyebutkan bahwa keinginan individu untuk menghindari konsumsi lemak makanan dan keinginan untuk menjadi kurus sangat terkait dengan kesadaran kesehatan dalam dirinya. Kesadaran kesehatan merupakan suatu hal yang penting dalam merancang intervensi kesehatan dan mensegmentasi target promosi kesehatan preventive health care behavior di masyarakat (Hong, 2009). Kesadaran kesehatan akan membuat individu lebih prihatin tentang kesehatannya dan cenderung termotivasi untuk meningkatkan atau menjaga kesehatannya (preventive health care behavior) (Michaelidou \& Hassan, 2008). Apabila individu obesitas memiliki kesadaran kesehatan, maka ia dapat dengan sengaja melakukan preventive health care behavior dengan cara menurunkan berat badannya dan menyadari bahwa ia memerlukan informasi terkait faktor apa saja yang akan mempengaruhi penurunan berat badannya, misalnya melakukan diet dan meningkatkan aktivitas fisik (Willet, 2002).

Dalam konteks dewasa awal, tugas perkembangan dewasa awal salah satunya adalah memilih pasangan hidup (Havighurst, 2004). Hal ini menyebabkan munculnya kebutuhan untuk tampil ideal di hadapan orang lain. Kesenjangan antara standar ideal yang berlaku di masyarakat membuat seseorang merasa kurang puas terhadap penampilan atau tubuhnya (body dissatisfaction) dan menimbulkan body image negatif (Sunartio dkk., 2012). Untuk mengatasi hal tersebut, individu obesitas yang memasuki dewasa awal akan melakukan integrasi perilaku berupa tindakan preventive health care behavior seperti sering berolahraga, melakukan positif diet seperti konsumsi makanan sehat seperti sayur, buah-buahan, biji-bijian, ikan, dan susu non-lemak, dan melakukan negatif diet seperti menghindari mentega / margarin, zat tambahan kimia (misalnya, pengganti gula), soda, dan makanan yang digoreng. Hal ini dilakukan demi tampil ideal dan mencegah kenaikan berat badan (Tabacchi, 1987). Individu obesitas yang sudah menerapkan preventive health care behavior artinya individu tersebut peka terhadap bahaya kesehatanya, dan membuatnya lebih bertanggung jawab atas kondisi kesehatannya (Kraft \& Goodell, 1993).

Pada penelitian yang dilakukan oleh Grunvald (2014), aspek terpenting dari keberhasilan pengelolaan berat badan serta perubahan gaya hidup jangka panjang adalah dukungan, bimbingan dan keterampilan yang diperoleh individu obesitas dari ahli kesehatan dan sumber informasi kesehatan yang lengkap. Pada kasus obesitas yang serius biasanya diberikan tindakan operasi bariatric. Operasi bariatrik adalah prosedur pembedahan yang dirancang untuk menghasilkan penurunan berat badan yang substansial (Nursalim \& Wisnu, 2012).

Bagiastra dan Griandhi (2019) mengatakan bahwa dalam upaya menganggulangi obesitas, pemerintah 
Indonesia mengadakan program preventif health care behavior berupa program positive deviance (PD). Program tersebut merupakan program baru di dunia kesehatan. Tujuan dari adanya program ini adalah pencegahan dini. Program ini mengupayakan terjadinya perubahan pola dan perilaku makan seperti mengurangi konsumsi makanan atau minuman manis dan berlemak, mengurangi konsumsi makanan cepat saji (junk food), memperbanyak konsumsi buah dan sayur, dan memperbanyak aktivitas fisik. Program ini dimulai dari lingkungan keluarga, sekolah hingga pelayanan kesehatan. Memberikan informasi, pengetahuan serta keterampilan tentang kesehatan adalah salah satu bentuk dari program PD ini. Dalam hal ini Kementerian Kesehatan menganjurkan kepada semua masyarakatnya untuk sadar dan tahu bagaimana kondisi kesehatan (health consciousness) dan tubuh masingmasing (Bagiastra \& Griandhi, 2019). Salah satu cara yang dapat dilakukan oleh masyarakat adalah dengan menghitung skor BMI, untuk mengetahui apakah indvidu tersebut mengalami obesitas atau tidak. Ketika seorang individu tahu bahwa dirinya mengalami obesitas dan akan dihadapkan pada sebuah risiko kesehatan (health consciousness), individu tersebut dapat langsung melakukan tindakan preventive health care behavior berupa program positive deviance (PD) yang telah dibuat oleh pemerintah.

Berdasarkan uji beda variabel kesadaran kesehatan (health consciousness) dan preventive health care behavior yang ditinjau dari jenis kelamin (laki-laki dan perempuan) menunjukan tidak terdapat perbedaan yang signifikan pada kedua variabel tersebut. Hal ini menunjukan bahwa jika dilihat dari faktor demografis, health consciousness yang dimiliki laki-laki dan perempuan yang mengalami obesitas tidak miliki perbedaan yang signifikan. Demikian pula, tidak ada perbedaan preventive health care behavior pada individu obesitas lakilaki dan perempuan. Penemuan ini sejalan dengan penelitian yang dilakukan oleh
Gould (1990) dan Dutta-Bergman (2004), bahwa kesadaran kesehatan dan preventive health care behavior relatif tidak bergantung pada pengaruh demografis, faktor yang dapat menyebabkan keduanya tidak terdapat perbedaan adalah pengaruh eksternal lingkungan (Lazarfield, dalam Suchman, 1967) karena partisipan umumnya berada di wilayah yang jaraknya berdekatan, sehingga kondisi lingkungan dan gaya hidup yang relatif sama (Silitonga, 2010). Hal ini berdampak juga pada tingkat kesadaran kesehatan dan preventive health care behavior laki-laki ataupun perempuan.

Berdasarkan perhitungan mean hipotetik terhadap kelompok subjek, ditemukan bahwa $80,5 \%$ dari 82 partisipan memiliki tingkat kesadaran kesehatan dikategori tinggi dan sisanya $19,5 \%$ berada di kategori sedang. Hal ini menunjukan bahwa individu yang mengalami obesitas sudah cukup sadar akan kondisi kesehatannya. Sementara itu, kategorisasi subjek penelitian pada variabel preventive health care behavior menunjukan bahwa $87,8 \%$ dari 82 partisipan yang mengalami obesitas sudah menerapkan preventive health care behavior dalam kesehariannya, sedangkan sisanya yaitu $12,2 \%$ belum sepenuhnya menerapkan preventive health care behavior. Bentuk perilaku yang tidak tergolong dalam preventive health care behavior diantaranya individu tidak melakukan pemeriksaan rutin kondisi giginya kepada dokter dan kurangnya memperhatikan kandungan garam dalam makanan yang dikonsumsi.

Berdasarkan paparan di atas, terlihat bahwa variabel kesadaran kesehatan berperan signifikan terhadap terbentuknya tindakan preventive health care behavior. Adapun kelemahan dari penelitian ini adalah peneliti tidak menggali lebih dalam terkait faktor-faktor yang berkaitan dengan kedua variabel, hal ini menjadi salah satu unsur yang dapat berpengaruh pada hasil penelitian. Kemudian, singkatnya jangka waktu pengambilan data membuat penelitian ini hanya mendapatkan 82 partisipan. 


\section{SIMPULAN}

Berdasarkan hasil penelitian yang telah dilakukan, model regresi ini sudah layak digunakan untuk memprediksi variabel kriteria penelitian yaitu preventive health care behavior. Hasil uji regresi linear menunjukkan bahwa kesadaran kesehatan berperan secara signifikan terhadap preventive health care behavior pada individu yang mengalami obesitas.

\section{SARAN}

Peneliti selanjutnya diharapkan dapat menambahkan waktu penyebaran kuesioner demi mendapatkan lebih banyak partisipan sehingga populasi obesitas lebih dapat terwakilkan. Peneliti selanjutnya disarankan untuk menambah pertanyaanpertanyaan ataupun kuesioner pendukung yang dapat menggali lebih dalam faktorfaktor yang terkait dengan kedua variabel. Selain itu, penelitian selanjutnya juga dapat melakukan modifikasi terhadap alat ukur kesadaran kesehatan dan preventive health care behavior, sehingga lebih menggambarkan kedua variabel tersebut berdasarkan kondisi masyarakat Indonesia.

Hasil penelitian ini menunjukkan bahwa terdapat peran yang signifikan dari kesadaran kesehatan terhadap preventive health care behavior. Oleh karena itu, peneliti berharap tenaga medis khususnya ahli di bidang gizi dan institusi terkait dapat membuat sebuah program preventif ataupun intervensi yang memberikan edukasi pentingnya kesadaran kesehatan (health consciousness). Dengan adanya program tersebut, peneliti berharap individu obesitas tersebut dapat termotivasi untuk segera melakukan upaya preventif demi mencegah risiko terburuk yang terjadi.

\section{DAFTAR PUSTAKA}

Arikunto, S (2010). Prosedur penelitian suatu pendekatan praktik. Rineka Cipta.

Ansari, S., Haboubi, H., \& Haboubi, N. (2020). Adult obesity complications:
Challenges and clinical impact. Therapeutic Advances in Endocrinology and Metabolism, 11, 14. doi: 10.1177/2042018820934955.

Azkia, F.I., \& Wahyono, T.Y. (2018). Hubungan pola konsumsi makanan berisiko dengan obesitas sentral pada wanita usia 25-65 tahun di Bogor tahun 2011-2012. Jurnal Epidemiologi Kesehatan Indonesia, 2(1), $12-$ 28.doi: 10.7454/epidkes.v2i1.1675.

Azwar, S. (2010). Penyusunan skala psikologi (edisi 1.). Pustaka Pelajar.

Badan Penelitian dan Pengembangan Kesehatan Kementerian RI. (2018). Riset Kesehatan Dasar (Riskesdas) 2018.

http://www.kesmas.kemkes.go.id/asse ts/upload/dir_519d41d8cd98f00/files/ Hasil-riskesdas-2018_1274.pdf pada 24 Februari 2020.

Bagiastra, N. \& Griandhi, N. M. (2019). Model pengaturan anti obesitas dalam rangka penguatan serta peningkatan derajat kesehatan masyarakat di Indonesia. Jurnal Ilmu Sosial dan Humaniora, 8(2), 242-249. http://dx.doi.org/10.23887/jishundiksha.v8i2.22377.

Basuki, G., \& Hartati, S. (2013). Makna obesitas. Empati, 2(3), 1-8.

Becker, M. H. (1985). Patient adherence to prescribed therapies. Medical Care, 23 (May), 539-555. https://doi.org/10.1097/00005650198505000-00014.

Chou, S. Y., Grossman, M., \& Saffer, H. (2004). An economic analysis of adult obesity: Results from the behavioral risk factor surveillance system. Journal of Health Economics, 23, 565587. 
Creswell, J. W. (2012). Research design pendekatan kualitatif, kuantitatif, dan mixed. Pustaka Pelajar.

Creswell, J. W (2014). Research design: qualitative, quantitative and mixed methods approaches, 4 Edition. Sage.

DetikNews (2019, Januari 30). Derita sunarti $148 \mathrm{~kg}$ : sesak napas hingga beraktivitas ngesot.

https://news.detik.com/berita-jawabarat/d-4407287/derita-sunarti-148-

kg-sesak-napas-hingga-

beraktivitasngesot?_ga=2.245962244.

1491323730.1586178074

23088227.1586178074 .

Deurenberg, P., Yap, M., \& Van Staveren, W. (1998). Body mass index and percent body fat: A meta analysis among different ethnic groups. International Journal of Obesity, 22, 1164-1171.

https://doi.org/10.1038/sj.ijo.0800741

Direktorat Jenderal Pencegahan dan Pengendalian Penyakit Kementerian Kesehatan Republik Indonesia. (2020). Rencana aksi program P2P 2020-2024. $\quad$ https://erenggar.kemkes.go.id/file2018/eperformance/1-79022-2tahunan098.pdf.

Dewi, M.C. (2015). Faktor-faktor yang menyebabkan obesitas pada anak. Majority, 4(8), 53-56.

Dodel, M., \& Mesch G. (2017) Cybervictimization preventive behavior: A health belief model approach. Computer Human Behavior, 68,359367.

Djaiman, S. P., Sari, K., \& Kusumawardani, N. (2017). Metaanalisis: Pencegahan obesitas pada anak sekolah. Media Litbangkes, 27 (1), 39-48. http://dx.doi.org/10.22435/mpk.v27i1 $.4838 .39-48$.

Drewnowski, A., Brunzebl, J.D., Sande, K., Iverius, P.H., \& Greenwood M.R. (1985). Sweet tooth reconsidered: taste responsiveness in human obesity. Physio Behav, 35, 617622 doi: $10.1016 / 0031-$ 9384(85)90150-7.

Ghozali, I. (2011). Aplikasi analisis multivariate dengan program SPSS. Badan Penerbit Universitas Diponegoro.

Gould, S. J. (1988). Consumer attitudes toward health and health care: A differential perspective. Journal of Consumer Affairs, 22(1), 96-118. doi: 10.1111/j.17456606.1988.tb00215.x.

Gould, S. J. (1990). Health consciousness and health behavior: The application of a new health consciousness scale. American Journal of Preventive Medicine, 6(4), 228-237.

Grunvald, E. (2014). Medical management of obesity: A comprehensive review. Clinical Obstetrics and Gynecology,57(3), 465-484. doi: 10.1097/GRF.000000000000004 1 .

Hadi, H (2004). Gizi lebih sebagai tantangan baru dan implikasinya terhadap kebijakan pembangunan kesehatan nasional. Jurnal Gizi Klinik Indonesia, $1(2)$, 4754. https://doi.org/10.22146/ijen.173 94.

Harlan, J. (2018). Analisis regresi linear. Penerbit Gunadarma.

Hong, H. (2009). Scale development for measuring health consciousness: reconceptualization. 
Proceedings of the 12th Annual International Public Relations Research Conference: Research That Matters to the Practice, Florida, F212-233.

Hoque, M., Alam, M., \& Nahid,K. (2018). Health consciousness and its effect on perceived knowledge, and belief in the purchase intent of liquid milk: consumer insights from an emerging market. Foods, 7(9), 150. https://doi.org/10.3390/foods7090150

Indrawati, L. (2014). Hubungan antara pengetahuan, sikap, persepsi, motivasi, dukungan keluarga dan sumber informasi pasien penyakit jantung koroner dengan tindakan pencegahan sekunder faktor risiko (studi kasus di RSPAD Gatot Soebroto Jakarta). Jurnal Ilmiah Widya, 2(3), 30-36.

Iversen, A. C., \& Kraft, P. (2006). Does socio-economic status and healthconsciousness influence how women respond to health related messages in media?. Health Education Research, 21(5), 601-610. https://doi.org/10.1093/her/cyl014.

Jayanti, R. K., \& Burns, A. C. (1998). The antecedents of preventive health care behavior: An empirical study. Journal of The Academy of Marketing Science, $26 \quad$ (1), 6-15. https://doi.org/10.1177/00920703982 61002.

Kambu, Y., Waluyo, A., \& Kuntarti, K. (2016). Umur orang dengan HIV AIDS (ODHA) berhubungan dengan tindakan pencegahan penularan HIV. Jurnal Keperawatan Indonesia, 19(3), 200-207.

Kim, D.H. (2018). Association between subjective obesity status and smoking behavior among normal-weight women. Health Education \& Behavior,45(3), 394-400. https://doi.org/10.1177/10901981177 28992.

Kraft, F. B., \& Goodell, P. W. (1993). Identifying the health conscious consumer. Journal of Health Care Marketing, Fall, 18-25.

Kurdanti, W., Suryani, I. , Syamsiatun, N. H., Siwi, L.P., Adityanti, M.M., Mustikaningsih, D., \& Sholihah, K. I. (2015). Faktor-faktor yang mempengaruhi kejadian obesitas pada remaja. Jurnal Gizi Klinik Indonesia, $11 \quad$ (4), 179-190. https://doi.org/10.22146/ijen.22900.

Kutresnaningdian, F., \& Albari (2012). Peran kesadaran kesehatan dan perhatian pada keamanan makanan terhadap sikap dan minat konsumen dalam membeli makanan organik. Jurnal Ilmu Manajemen, 2(1), 1-15. DOI: $10.32502 /$ jimn.v2i1.334.

Michaelidou, N., \& Hassan, L. M. (2008). The role of health consciousness, food safety concern and ethical identity on attitudes and intentions towards organic food. International Journal of Consumer Studies, 32(1), 163-170. https://doi.org/10.1111/j.14706431.2007.00619.x.

Misnadiarly. (2007). Obesitas sebagai faktor resiko beberapa penyakit. Pustaka Obor Populer.

Moorman, C. \& Matulich,E. (1993). A model of consumers' preventive health behaviors: The role of health motivation and health ability. Journal of Consumer Research, 20, 208-228. https://doi.org/10.1086/209344.

Mulyana, D. (2002). Pengaruh terpaan informasi kesehatan di televisi terhadap sikap hidup sehat keluarga. Mediator, 3(2), 309-322. 
https://doi.org/10.29313/mediator.v3i 2.779 .

Noer, E. R., Kustanti, E. R., Fitriyanti, A. R. (2018). Perilaku gizi dan faktor psikososial remaja obes. Jurnal Gizi Indonesia (The Indonesian Journal of Nutrition), $\quad$ 6(2), 109-113. https://doi.org/10.14710/jgi.6.2.109113.

Nursalim, A., \& Wisnu, W. (2013). Mortality and morbidity benefit of bariatric surgery among obese patients: An evidence based report. Journal of the Indonesian Medical Association, 62(3), 107-112.

Rajaratenam, S. G., Martini, R. D., \& Lipoeto, N. I. (2014). Hubungan tingkat pengetahuan dan sikap dengan tindakan pencegahan osteoporosis pada wanita usila di kelurahan Jati. Jurnal Kesehatan Andalas, 3(2), 225-228.

Republika.co.id (2019, September 09). Sempat berbobot $120 \mathrm{~kg}$, Kemal pernah sesak napas saat tidur. https://republika.co.id/berita/pxjgoz41 4/sempat-berbobot-120-kg-kemalpernah-sesak-napas-saat-tidur.

Sandjaja \& Sudikno (2005). Prevalensi gizi lebih dan obesitas penduduk dewasa di indonesia. Gizi Indo, 31, 1-7. doi: 10.36457/gizindo.v28i2.21.

Sari, A.M., Ernalia,Y., \& Bebasari, E. (2017). Hubungan aktivitas fisik dengan kejadian obesitas pada siswa SMPN di Pekanbaru. JOM FK, 4(1), $1-8$.

Shahnazi, H., Livani, M.A., Pahlavanzadeh, B., Rajabi, A., Hamrah, M.S., \& Charkazi, A. (2020). Assessing preventive health behaviors from COVID-19: A cross sectional study with health belief model in Golestan province, Northern of Iran. Infectious Diseases of Poverty, 9, 157.

Silitonga, D. P. (2010). Tahapan perkembangan metropolitan JABODETABEK berdasarkan perubahan pada aspek lingkungan. Jurnal Perencanaan Wilayah dan Kota, 21(3), 197 - 214.

Suchman, E. A. (1967). Preventive health behavior: a model for research on community health campaigns. Journal of Health and Social Behavior, 8(3), 197-209.

https://doi.org/10.2307/2948374.

Sugiyono (2013). Metode penelitian kuantitatif, kualitatif, dan $R \& D$. Alfabeta.

Sugiyono. (2016). Metode penelitian kuantitatif, kualitatif, dan $R \& D$. Alfabeta.

Sunartio, L., Sukamto, M. E., \& Dianovianina, K. (2012). Social comparison dan body dissatisfaction pada wanita dewasa awal. HUMANITAS: Indonesian Psychological Journal, 9(2), 157-168.

Tabacchi, M. H. (1987). Targeting the health-conscious consumer. Cornell Hotel and Restaurant Administration Quarterly, 28(3), 21-24.

Wellman, N. S \& Friedberg, B., (2002). Causes and consequences of adult obesity: Health, social and economic impact in the united states. Asia Pacific J Clin Nutr, 11(Suppl), S705S709. https://doi.org/10.1046/j.14406047.11.s8.6.x.

Werle, C (2011). The determinants of preventive health behavior: literature review and research perspectives. HAL Archive-Ouvertes. http://hal.grenoble- 
em.com/file/index/docid/638266/filen ame/Werle_Determinants_of_prevent ive health behavior_WP_FV.pdf.

Widhiarso, W. (2010). Analisis butir dalam pengembangan pengukuran psikologi. http://widhiarso.staff.ugm.ac.id/files/ widhiarso_2001_-

_analisis_butir_dalam_pengembanga n_pengukuran_psikologi.pdf pada 11 Mei 2020.
Wulansari, A., Martianto, D., \& Baliwati, Y. F. (2016). Estimasi kerugian ekonomi akibat obesitas pada orang dewasa di Indonesia. Jurnal Gizi Pangan, 11(2), 159-168.

doi: https://doi.org/10.25182/jgp.2016 $.11 .2 . \% 25 \mathrm{p}$. 